\title{
Millets: a solution to agrarian and nutritional challenges
}

\author{
Ashwani Kumar ${ }^{1,2^{*}}$, Vidisha Tomer ${ }^{2}$, Amarjeet Kaur ${ }^{1}$, Vikas Kumar ${ }^{2}$ and Kritika Gupta ${ }^{2}$
}

\begin{abstract}
World is facing agrarian as well as nutritional challenges. Agricultural lands with irrigation facilities have been exploited to maximum, and hence we need to focus on dry lands to further increase grain production. Owing to low fertility, utilization of dry lands to produce sufficient quality grains is a big challenge. Millets as climate change compliant crops score highly over other grains like wheat and rice in terms of marginal growing conditions and high nutritional value. These nutri-cereals abode vitamins, minerals, essential fatty acids, phyto-chemicals and antioxidants that can help to eradicate the plethora of nutritional deficiency diseases. Millets cultivation can keep dry lands productive and ensure future food and nutritional security.
\end{abstract}

Keywords: Millets, Dry lands, Nutrition, Nutri-cereals, Micronutrient deficiency

\section{Background}

Progress in scientific knowledge and technological innovations have led mankind into yet another stage of modern civilization. Application of novel research strategies into fundamental and translational research has brought an all-round development. In agriculture, strategized technological innovations, viz. development and selection of high yielding variety, use of synthetic fertilizers and pesticides, mechanization and irrigation facilities, have resulted in sufficient availability of food. Estimated global cereal production was 2605 million tons in 2016 and was forecasted to be 2597 million tons in 2017 [1]. Several short-sighted measures have enhanced productivity but have undermined sustainability and are eroding the very capacity of resource base leading to nutrient deficient saline soil and lowering water beds. In addition, changing climatic conditions have further hastened the vulnerability of farmers towards declining crop production. Dry lands constitute $40 \%$ of the global land surface and are home for about $1 / 3$ rd of the global population. These low fertile soils are predicted to elevate

\footnotetext{
*Correspondence: ashwanichandel480@gmail.com

${ }^{1}$ Food Science and Technology, Punjab Agricultural University, Ludhiana, Punjab 141004, India

Full list of author information is available at the end of the article
}

up to $50-56 \%$ in $2100 \mathrm{AD}$, and $78 \%$ of dry land expansion is expected to occur in developing countries [2-4]. According to the report of World Bank, hunger is a challenge for 815 million people worldwide [5]. The spate of farmer's suicides in an agriculture-based country like India has reached to an average of 52 deaths/day, and reports of farmers selling their blood to earn a livelihood in drought-hit region of the country depict the severity of the agrarian crisis [6].

Sustainable crop substitutes are needed to meet the world hunger (cereal demand) and to improve income of farmers. Role of millets cannot be ignored for achieving sustainable means for nutritional security (Fig. 1). International crops research institute for the semi-arid tropics (ICRISAT) is focusing on increasing the productivity of millets and has included finger millet (Eleucine corcana) as sixth mandatory crop [3, 4]. Millets abode vital nutrients and the protein content of millets grains are considered to be equal or superior in comparison to wheat (Triticum aestivum), rice (Oryza sativa), maize (Zea mays) and sorghum (Sorghum bicolor) grains [7]. The role of millets in designing the modern foods like multigrain and gluten-free cereal products is well known [8]. Due to the richness of millets in polyphenols and other biological active compounds, they are also considered to impart role in lowering rate of fat absorption, slow release of 


\begin{tabular}{|c|c|c|c|}
\hline \multicolumn{4}{|c|}{ Millets: an approach for sustainable agriculture and healthy world } \\
\hline$\downarrow$ & $\sqrt{ }$ & $\checkmark$ & $\sqrt{ }$ \\
\hline $\begin{array}{l}\text { Food Secuity } \\
\text { - Sustainable food } \\
\text { source for combating } \\
\text { hunger in changing } \\
\text { world climate } \\
\text { - Resistant to climatic } \\
\text { stress, pests and } \\
\text { diseases }\end{array}$ & $\begin{array}{l}\text { Nutritional Secuity } \\
\text { - Rich in } \\
\text { micronutrients like } \\
\text { calcium, iron, zinc, } \\
\text { iodine etc. } \\
\text { - Rich in bioactive } \\
\text { compounds } \\
\text { Better amino acid } \\
\text { profile }\end{array}$ & $\begin{array}{l}\text { Safety from diseases } \\
\text { - Gluten free: a } \\
\text { substitute for wheat } \\
\text { in celiac diseases } \\
\text { - Low GI: a good food } \\
\text { for diabetic persons } \\
\text { - Can help to combat } \\
\text { cardiovascular } \\
\text { diseases, anaemia, } \\
\text { calcium deficiency } \\
\text { etc. }\end{array}$ & $\begin{array}{l}\text { Economic secuuity } \\
\text { - Climate resilient crop } \\
\text { - Sustainable income } \\
\text { source for farmers } \\
\text { - Low investment } \\
\text { needed for production } \\
\text { - Value addition can } \\
\text { lead to economic } \\
\text { gains }\end{array}$ \\
\hline
\end{tabular}

Fig. 1 Benefits of millets in a nutshell

sugars (low glycaemic index) and thus reducing risk of heart disease, diabetes and high blood pressure. Due to increased awareness regarding the health promoting profile of millets, inclination towards their consumption has been observed. Present review envisages the agrarian requirements, nutritional information and health benefits imparted by these grains. Review also explores the millet-based products made traditionally along with the latest researches conducted worldwide.

\section{Agrarian importance of millets}

The demand of food will increase proportionately with growth in world population. At present about $50 \%$ of world's total calorie intake is derived directly from cereals [9]. Rice, wheat and maize have emerged as the major staple cereals with a lesser extent of sorghum and millets. Sharma [10] reported that an increase in the areas of crops with intense water requirements like rice, sugarcane (Saccharum officinarum) and cotton (Gossypium) has resulted in the increase in $0.009 \%$ in the distance between the ground level and ground water table and this loss is approximately equivalent to a loss of $7191 \mathrm{~L}$ of ground water per hectare. There is a lesser possibility of increasing the production of major staple cereals as the world is already facing the challenges of increase in dry lands and deepening of ground water level $[3,10]$. According to the report of the National Rainfed Area Authority (NRAA) even after realizing the full irrigation potential, about half of the net sown area will continue to remain rainfed [11]. This alarms the need of shifting to the alternative of current cereal staples.

Millets cultivation can be a solution to this problem as these can grow on shallow, low fertile soils with a $\mathrm{pH}$ of soil ranging from acidic 4.5 to basic soils with $\mathrm{pH}$ of
8.0 [12]. Millets can be a good alternative to wheat especially on acidic soils. Rice is very sensitive to saline soils and has poor growth and yield on a soil having salinity higher than $3 \mathrm{dS} / \mathrm{m}$ [13]. On the other hand, millets like pearl millet (Pennisetum glaucum) and finger millet can grow up to a soil salinity of $11-12 \mathrm{dS} / \mathrm{m}$. Millets have a low water requirement both in terms of the growing period and overall water requirement during growth. The rainfall requirement of certain millets like pearl millet and proso millet (Panicum miliaceum) is as low as $20 \mathrm{~cm}$, which is several folds lower than the rice, which requires an average rainfall of $120-140 \mathrm{~cm}$ [13]. Most of the millets mature in 60-90 days after sowing which makes them a water saving crop. Barnyard millet (Echinochloa frumentacea) has the least maturation time of 45-70 days among millets, which is half to the rice maturation (120-140 days) time [14]. Millets fall under the group of $\mathrm{C} 4$ cereals. $\mathrm{C} 4$ cereals take more carbon dioxide from the atmosphere and convert it to oxygen, have high efficiency of water use, require low input and hence are more environment friendly. Thus, millets can help to phase out climatic uncertainties, reducing atmospheric carbon dioxide, and can contribute in mitigating the climate change. The major millets and their growing conditions in comparison to the staple cereals, i.e. rice and wheat, are tabulated in Table 1.

Scientific interventions in terms of the use of molecular biomarkers, sequence information, creation of mapping populations and mutant have led to the development and release of high yielding varieties of millets throughout the world $[22,29]$. Newly developed hybrids are resistant to diseases and has increased per hectare production as compared to their parent varieties [29,30]. Millets have abundant natural diversity, and the release of new hybrids 


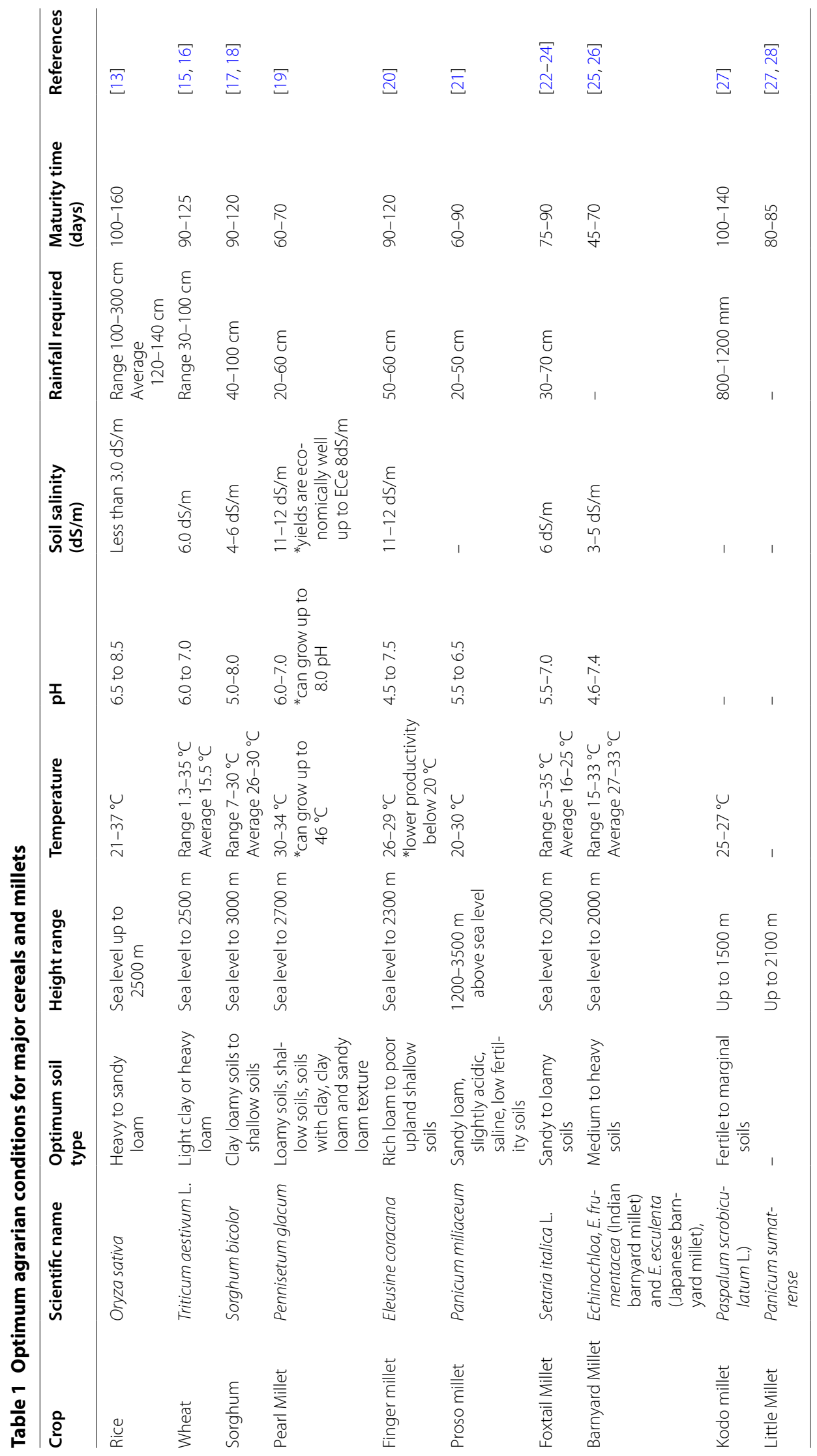


increases this variation by several folds. For example, pearl millet has approximately 140 species or subspecies belonging to the genus Pennisetum [31] and further maintenance of the gene bank accessions has increased this number to 65,400 . The primary global collection of pearl millet is at ICRISAT with $33 \%$ of the world's gene bank accessions. The largest gene accessions for finger millet, i.e. approximately $27 \%$ of the world's total 35,400 accessions, are maintained by Bureau for Plant Genetic Resources, India. Chinese Institute of Crop Germplasm Resources (ICGR) maintains world's $56 \%$ of the accessions of foxtail millet (Setaria italica), while National Institute of Agrobiological Sciences in Japan maintains the largest proso millet accessions collection with $33 \%$ of the world's approximately 17,600 genebank accessions [32]. In addition to the improvement in varieties, the advancements in the post-harvest operations of millets have eased their processing. In past, due to the lack of suitable machinery, traditional methods like pounding, winnowing, etc., were used for the decortication of millet grains. These methods were labour intensive, and hence, the production of edible millets was limited [33]. Millet-specific threshers, decorticator, destoners and polishers have been designed by intervention of government agencies as well as private companies. These recent developments in post-harvest operations of millets have eased their processing and have paved way for utilization of millets in the development of food products. The cultivation of millets can provide an overall solution to the existing agrarian challenges and can prove a milestone in achieving United Nations commitment to end malnutrition in all its forms by 2030 [34].

\section{Nutritional importance}

World is in the clinch of several health disorders and chronical diseases. As per 2016 Global Nutrition report, $44 \%$ population of 129 countries (countries with available data) experience very serious levels of undernutrition, adult overweight and obesity [35]. A nutrient imbalanced diet is responsible for most of these diseases. According to the estimates of United Nations Food and Agriculture Organization, about 795 million people (10.9\% of world population in 2015) were reported undernourished. While on the other hand more than 1.9 billion (39\% of world's population) adults $\geq 18$ years of age were overweight and further $13 \%$ were reported to be obese [36, 37]. The average body mass index (BMI) of the world's population was reported to be $24 \mathrm{~kg} / \mathrm{m}^{2}$ in 2014 which is above the WHO standards for optimum health (21 to $23 \mathrm{~kg} / \mathrm{m}^{2}$ ) [38]. Obesity-related complications like cardiovascular diseases and diabetes have already been declared as epidemic by the world health organization. India is the home of world's largest undernourished population. About 194.6 million people, i.e. $15.2 \%$ of total population of India, are undernourished. According to the 2017 Global Hunger Index report, India ranked 100th among 119 countries. The score of India is even poorer than Nepal, Sri Lanka and Bangladesh [39]. Protein energy malnutrition (PEM) was reported to result in $4,69,000$ deaths with 84,000 deaths from the deficiency of other vital nutrients such as iron, iodine and vitamin A [40]. Obesity is also a major health concern in India with the prevalence rate of $11 \%$ in men and $15 \%$ in women. Status of malnutrition in world and India is presented in Table 2. Millets secure sixth position in terms of world agricultural production of cereal grains and are still a staple food in many regions of world. These are rich source of many vital nutrients and hence, promise an additional advantage for combating nutrient deficiencies in the third world countries.

\section{Macronutrients}

Millets are nutritionally similar or superior to major cereal grains. The additional benefits of the millets like gluten-free proteins, high fibre content, low glycaemic index and richness in bioactive compounds made them a suitable health food [27]. The average carbohydrates content of millets varies from 56.88 to $72.97 \mathrm{~g} / 100 \mathrm{~g}$. Least carbohydrate content has been reported in barnyard millet $[8,46]$. The protein content of all the millets is comparable to each other with an average protein content of 10 to $11 \%$, except finger millet, which has been reported to contain protein in the range of 4.76 to $11.70 \mathrm{~g} / 100 \mathrm{~g}$ in different studies [47-49]. Finger millet protein is rich in essential amino acids like methionine, valine and lysine, and of the total amino acids present, $44.7 \%$ are essential amino acids [50]. This content is higher than the required 33.9\% essential amino acids in FAO reference protein [51]. The mean value of protein reported from different studies depicts that proso millet has the highest protein content among millets (Table 3). The protein present in proso millet is comparable to wheat, but the amount of essential amino acids like leucine, isoleucine and thiamine is much higher in proso millet. The lipid content of millets as a group is comparable to that of wheat and rice (2.0\% in wheat and $2.7 \%$ in rice) and ranges from 1.43 to $6 \mathrm{~g} / 100 \mathrm{~g}$. Among millets, the least lipid content has been reported in finger millet while the highest lipid content has been reported in pearl millet $[46,49,52]$. Millets are richest source of fibres, i.e. crude fibre as well as dietary fibre. Barnyard millet is the richest source of crude fibre with an average content of $12.8 \mathrm{~g} / 100 \mathrm{~g}$ [8]. The highest dietary fibre content, i.e. $38 \%$ and $37 \%$, has been reported to be in little millet (Panicum sumatrense) and kodo millet (Paspalum scrobiculatum), respectively. This content is $785 \%$ higher than rice and wheat; this make millets 
Table 2 Status of malnutrition in world and India

Agencies/studies

References

World

2 billion people suffer from micronutrient malnutrition

United Nations International Children's Emergency Fund,

800 million people suffer from calorie deficiency

International Food Policy Research Institute

million adults are overweight

One in 12 adults has type 2 diabetes

159 million children under age 5 are stunted (too short for their

age)

50 million children under age 5 are wasted (Less weight for their height)

41 million children under age 5 are overweight (More weight for their height)

India

60 million children underweight (highest in world)

World bank

$30 \%$ low birth weight babies

$75 \%$ pre-school children suffer from iron deficiency anaemia

$85 \%$ districts have endemic iodine deficiency

$35.7 \%$ of children under five are underweight; $58.4 \%$ of children between 6 and 59 months are anaemic; 53\% of (non-pregnant) women are anaemic

Global hunger index score $=31.4$ (serious hunger situation)

$21 \%$ of children in India suffers from wasting

Ranked 34th among leading countries with a serious hunger situation

Ranked third behind only Afghanistan and Pakistan (In south Asia)

$17.3 \%$ stunted

$15.1 \%$ wasted

$29.4 \%$ children underweight

9.4\% severely underweight

51 million people suffer from diabetes which is expected to increase to 79.4 million by 2030 (the increasing consumption of highly polished rice grains and decreasing consumption of coarse cereals contributes to this trend)

$5.3 \%$ children obese

Table 3 Proximate composition of different millets (per $100 \mathrm{~g}$ ) [7, 8, 46, 48, 57-59]

\begin{tabular}{llclccc}
\hline Millet type & Carbohydrates & Protein & Fat & Crude fibre & Ash & Calorific value \\
\hline Rice & $82.86 \pm 7.53$ & $4.99 \pm 1.38$ & $1.90 \pm 1.03$ & $1.63 \pm 0.42$ & $0.99 \pm 0.42$ & $369 \pm 27.82$ \\
Wheat & $69.88 \pm 1.66$ & $13.78 \pm 1.40$ & $2.81 \pm 0.18$ & $1.77 \pm 0.15$ & $1.63 \pm 0.26$ & $438 \pm 1.75$ \\
Sorghum & $72.97 \pm 2.25$ & $10.82 \pm 2.45$ & $3.23 \pm 1.60$ & $1.97 \pm 0.35$ & $1.70 \pm 0.66$ & 329.0 \\
Pearl millet & $69.10 \pm 1.52$ & $11.4 \pm 0.8$ & $4.87 \pm 0.12$ & $2.0 \pm 0.55$ & $2.13 \pm 0.21$ & 363.0 \\
Foxtail millet & $67.30 \pm 5.70$ & $11.34 \pm 0.91$ & $3.33 \pm 0.76$ & $8.23 \pm 1.66$ & $3.37 \pm 0.12$ & $352 \pm 1.41$ \\
Finger millet & $71.52 \pm 3.59$ & $7.44 \pm 0.87$ & $1.43 \pm 0.12$ & 3.60 & $2.63 \pm 0.06$ & $334 \pm 2.82$ \\
Barnyard millet & $56.88 \pm 6.86$ & $10.76 \pm 1.11$ & $3.53 \pm 1.19$ & $12.8 \pm 2.4$ & $4.30 \pm 0.26$ & 300.0 \\
Proso millet & $67.09 \pm 4.79$ & $11.74 \pm 0.86$ & $3.09 \pm 1.18$ & $8.47 \pm 3.4$ & $2.73 \pm 0.72$ & $352.5 \pm 1.62$ \\
Kodo millet & $63.82 \pm 7.94$ & $9.94 \pm 1.6$ & $3.03 \pm 1.03$ & $8.20 \pm 2.3$ & $2.83 \pm 0.40$ & $349.5 \pm 4.95$ \\
\hline
\end{tabular}

low glycaemic foods and hence a good choice for diabetic patients. In vitro studies of the soluble polysaccharides of finger millet (arabinose and xylose mainly) have proved them to be potent prebiotics and also possess wound dressing potential $[53,54]$. This resistant starch contributes towards dietary fibre, which acts as a prebiotic and hence enhances the health benefits of the millets [55]. Resistant starch also helps in the production of desirable metabolites such as short-chain fatty acids in the colon, especially butyrate, which helps to stabilize 
colonic cell proliferation as a preventive mechanism for colon cancer [56]. Table 3 gives the mean and standard deviation of the macronutrient content of millets as reported by various researchers.

\section{Micronutrients}

The minerals and vitamins are known as micronutrients as they are required in very small quantities. Minerals play an important role in the building of bones, clotting of blood, sending and receiving signals, keeping normal heart beat, cell energy production, transportation of oxygen, metabolize and synthesize fats and proteins, act as co-enzymes, provide immunity to the body and help nervous system work properly [60]. The mineral content in millets ranges from 1.7 to $4.3 \mathrm{~g} / 100 \mathrm{~g}$, which is several folds higher than the staple cereals like wheat (1.5\%) and rice $(0.6 \%)$. Calcium and iron deficiency is highly prevalent in India [61], and a large chunk of adult population is suffering from osteoporosis. Calcium content of finger millet is about eight times higher than wheat and being the richest source of calcium ( $348 \mathrm{mg} / 100 \mathrm{~g}$ ) it has the ability to prevent osteoporosis. Barnyard millet and pearl millet are the rich source of iron, and their consumption can meet the iron requirement of pregnant women suffering from anaemia. The iron content of barnyard millet is $17.47 \mathrm{mg} / 100 \mathrm{~g}$ which is only $10 \mathrm{mg}$ lower than the required daily value. Foxtail millet contains highest content of zinc $(4.1 \mathrm{mg} / 100 \mathrm{~g})$ among all millets and is also a good source of iron $(2.7 \mathrm{mg} / 100 \mathrm{~g})$ [57]. These nutrients, i.e. zinc and iron, play an important role in enhancing the immunity. Millets are also good source of $\beta$-carotene and $\mathrm{B}$-vitamins especially riboflavin, niacin and folic acid. The thiamine and niacin content of millets is comparable to that of rice and wheat. The highest thiamine content in millets, i.e. $0.60 \mathrm{mg} / 100 \mathrm{~g}$, is found in foxtail millet. Riboflavin content of the millets is several folds higher than the staple cereals, and barnyard millet $(4.20 \mathrm{mg} / 100 \mathrm{~g})$ has the highest content of riboflavin followed by foxtail millet $(1.65 \mathrm{mg} / 100 \mathrm{~g})$ and pearl millet $(1.48 \mathrm{mg} / 100 \mathrm{~g})$. The detail of micronutrient content of millets has been discussed in Table 4. The incorporation of millets in the diet can help to eradicate nutritional deficiencies. Platel [62] has proposed for the use of millet flour as a vehicle for iron and zinc fortification in India.

\section{Phenolic compounds}

Phenolic compounds form a very large group of compounds containing the phenol functional group as a fundamental component. Conveniently, these may be classified into phenolic acids, flavonoids and tannins. Phenolic acids are further sub-classified as hydroxybenzoic acids, hydroxycinnamic acids, hydroxyphenylacetic acids and hydroxyphenylpropanoic acids. Chandrasekara and Shahidi [63] determined and characterized the free, hydrolyzed (esterified and etherified) and bound phenolic compounds in millets by HPLC-DAD-ESI-MS ${ }^{\mathrm{n}}$. The highest amounts of hydroxybenzoic acid derivatives $(62.2 \mu \mathrm{g} / \mathrm{g})$ and flavonoids $(1896 \mu \mathrm{g} / \mathrm{g})$ were found in the soluble fraction of finger millet. Little millet $(173 \mu \mathrm{g} / \mathrm{g})$ and foxtail millet $(171 \mu \mathrm{g} / \mathrm{g})$ had the highest amount of hydroxycinnamic acid and their derivate in soluble form. The highest contribution to the total phenol content is in the form of the insoluble bound phenolics attached to the cell wall. Flavonoids are more prevalent in free form. Major phenols identified and quantified by different researchers are given in Table 5. Millets phenols are reported to have antioxidant, anti-mutagenic, anti-oestrogenic, anti-inflammatory, antiviral effects and platelet aggregation inhibitory activity [64]. Total antioxidant capacity of finger, little, foxtail and proso millets is higher due to their high total carotenoid and tocopherol content which varied from 78 to 366 and 1.3 to $4.0 \mathrm{mg} / 100 \mathrm{~g}$, respectively, in different millet varieties [65]. The beneficial effect of phenolics in diabetes is due to partial inhibition of amylase and $\alpha$-glucosidase during enzymatic hydrolysis of complex carbohydrates and delays the

Table 4 Comparison of micronutrients content of millets with the staple cereals $(\mathrm{mg} / 100 \mathrm{~g})[7,8,46,48,57-59]$

\begin{tabular}{|c|c|c|c|c|c|c|c|}
\hline Cereal grain & Calcium & Iron & Phosphorus & Zinc & Thiamine & Niacin & Riboflavin \\
\hline Rice & $0.12 \pm 0.07$ & $1.25 \pm 0.78$ & $0.52 \pm 0.02$ & 0.5 & $0.50 \pm 0.13$ & $5.56 \pm 1.76$ & $0.06 \pm 0.02$ \\
\hline Wheat & $43.41 \pm 3.69$ & $5.24 \pm 0.80$ & $357.74 \pm 26.54$ & 2.9 & $0.44 \pm 0.05$ & $4.31 \pm 1.00$ & $0.10 \pm 0.01$ \\
\hline Sorghum & $35.23 \pm 7.42$ & $5.29 \pm 1.28$ & $266.30 \pm 32.3$ & $3.01 \pm 0.89$ & 0.28 & 5.19 & 0.05 \\
\hline Pearl millet & $35 \pm 8.9$ & $10.3 \pm 7.0$ & 339 & - & $0.30 \pm 0.1$ & $1.11 \pm 1.3$ & $1.48 \pm 1.9$ \\
\hline Foxtail millet & $31 \pm 11$ & $3.5 \pm 1.2$ & 300 & 60.6 & 0.60 & $0.55 \pm 0.6$ & $1.65 \pm 2.2$ \\
\hline Finger millet & $348 \pm 3.5$ & $4.27 \pm 0.6$ & 250 & $36.6 \pm 3.7$ & $0.40 \pm 0.1$ & $0.80 \pm 0.9$ & $0.60 \pm 0.7$ \\
\hline Barnyard millet & $18.33 \pm 6.0$ & $17.47 \pm 2.0$ & - & $57.45 \pm 1.9$ & 0.33 & 0.10 & 4.20 \\
\hline Proso millet & $10 \pm 3.5$ & $2.2 \pm 1.2$ & 200 & - & 0.41 & 4.54 & 0.28 \\
\hline Kodo millet & $32.33 \pm 4.6$ & $3.17 \pm 1.3$ & 300 & $32.7 \pm 2.2$ & 0.15 & 0.09 & 2.0 \\
\hline
\end{tabular}


Table 5 Phenolic compound content ( $\mu \mathrm{g} / \mathrm{g}$ defatted meal) in different types of millets (Adapted from Chandrasekara and Shahidi [63]) (content of phenolic compounds in bound form)

\begin{tabular}{|c|c|c|c|c|c|c|}
\hline Phenolic compound & Pearl & Finger & Proso & Foxtail & Barnyard $^{c}$ & Kodo \\
\hline \multicolumn{7}{|c|}{ Hydroxybenzoic acid and derivatives } \\
\hline Methyl vanillate & 19.8 & - & - & - & - & - \\
\hline Protocatechuic acid & $11.8^{\mathrm{a}}$ & $23.1^{\mathrm{a}}, 48.2$ & 69.7 & 10.2 & - & 39.7 \\
\hline p-Hydroxybenzoic acid & $22^{\mathrm{a}}$ & $8.9^{\mathrm{a}}, 1.7$ & 55.4 & $14.6^{\mathrm{a}}, 5.63$ & - & 10.5 \\
\hline Vanillic & $16.3^{\mathrm{a}}, 7.08$ & $15.2^{\mathrm{a}}$ & 85.8 & $87.1^{\mathrm{a}}, 22.1$ & - & 40.1 \\
\hline Syringic & $17.3^{\mathrm{a}}$ & $7.7^{\mathrm{a}}$ & - & $93.6^{\mathrm{a}}$ & - & - \\
\hline Gentisic acid & $96.3^{\mathrm{a}}$ & $61.5^{\mathrm{a}}$ & - & $21.5^{\mathrm{a}}$ & - & - \\
\hline \multicolumn{7}{|c|}{ Hydroxycinnamic acid and derivatives } \\
\hline Caffeic acid & $21.3^{\mathrm{a}}$ & $16.6^{\mathrm{a}}, 11$ & - & $10.6^{\mathrm{a}}, 34$ & - & 276 \\
\hline$p$-Coumaric acid & $268.9^{a}, 53.5$ & 36 & 1188 & $2133.7^{\mathrm{a}}, 848$ & - & 767 \\
\hline Trans-ferulic acid & 637 & 331 & 332 & 631 & - & 1844 \\
\hline Cis-ferulic acid & 81.5 & 65.3 & 18.6 & 101 & - & 100 \\
\hline 8,8'-Aryl ferulic acid & - & - & - & 19.6 & - & 94.8 \\
\hline 5,5'-Di ferulic acid & 57 & 11.8 & 5.44 & 62.2 & - & 173 \\
\hline Flavonoids ${ }^{b}$ & 7.1 & 1896 & 1.9 & 169 & - & 179 \\
\hline
\end{tabular}

a values are taken from Dykes and Rooney [65] (expressed as $\mu \mathrm{g}$ phenolic acid/mg samples)

${ }^{b}$ Content of phenolic compounds in soluble fraction of millet grains

c Data not available

absorption of glucose, which ultimately controls the postprandial blood glucose levels.

\section{Other health benefits}

Sireesha et al. [66] has demonstrated the anti-hyperglycaemic and anti-lipidemic activities of the aqueous extract of foxtail millet (Setaria italica) in streptozotocin-induced diabetic rats. In the study, they reported the dose of $300 \mathrm{mg}$ of Setaria italica seed aqueous extract per kilo gram $(\mathrm{kg})$ body weight produced a significant fall $(70 \%)$ in blood glucose in diabetic rats after $6 \mathrm{~h}$ of administration of the extract. They also found lower levels of triglycerides, total LDL (low-density lipoproteins) and VLDL (very low-density lipoproteins) cholesterol and an increase in the levels of HDL (high-density lipoproteins) cholesterol in diabetic treated rats compared to those in diabetic untreated rats which demonstrates the hypolipidemic effect of aqueous extract. Choi et al. [67] studied the effect of dietary protein of Korean foxtail millet and found its importance in increasing insulin sensitivity and cholesterol metabolism. A remarkable reduction in insulin concentration of the rats fed with foxtail millet was demonstrated by this experiment. Lee et al. [68] investigated the effect of millet consumption on lipid levels and C-reactive protein concentration; it was found that hyperlipidemic rats fed with foxtail millet had decreased levels of triglycerides, which was in contrast to its previous researches [67]. Levels of $C$ reactive protein, which is an indicator of inflammation, were also found to decrease in foxtail millet fed rats. Aqueous and ethanolic extracts of kodo millet have been reported to produce a dose-dependent fall in fasting blood glucose [69]. Further millets are gluten free and might have anti-carcinogenic properties [65]. The health benefits of millets in a nutshell are given in Table 6.

\section{Effects of processing on millets}

Processing of millets decreases the anti-nutritional factors in millets and improves the bio-accessibility of nutrients. Many processing methods have been used traditionally like roasting/popping, soaking, germination and fermentation [80]. All these methods have been reported to have a significant impact on the nutritional value of the grain. Malting of millets improves access to nutrients and has been reported to increase the bioaccessibility of iron by $300 \%$ and of manganese by $17 \%$ [81]. The anti-nutritional factors decreased significantly with an increase in germination time due to hydrolytic activity of the enzyme phytase that increases during germination. The phytate content of millets can be reduced by germination as during the germination the hydrolysis of phytate phosphorus into inositol monophosphate takes place which contributes to the decrease in phytic acid. The tannins are also leached during soaking and germination of grains, and hence it results in the reduction in tannins $[82,83]$. Boiling and pressure cooking also result in reduction in tannins. Fermentation is known to reduce the anti-nutritional factors and hence improves 
Table 6 Benefits of millets in a nutshell

\begin{tabular}{|c|c|c|c|}
\hline Disease & Functional factor & Mechanism of action & References \\
\hline PEM & $\begin{array}{l}\text { Optimum carbohydrate } \\
\text { and high quality protein }\end{array}$ & Sustainable crop option in arid and semi-arid regions & {$[8]$} \\
\hline $\begin{array}{r}\text { Micronutrient } \\
\text { deficiencies }\end{array}$ & $\begin{array}{l}\text { High content of Iron, } \\
\text { iodine, zinc, calcium, } \\
\text { magnesium and other } \\
\text { micronutrients com- } \\
\text { pared to other cereals }\end{array}$ & $\begin{array}{l}\text { Inclusion of millets in diet } \\
\text { Bio-fortification of staple cereals }\end{array}$ & {$[70,71]$} \\
\hline Obesity & Dietary fibre & $\begin{array}{l}\text { Controls release of carbohydrates } \\
\text { Soluble fibre leads to highly viscous intestinal contents that possess gelling properties } \\
\text { and could delay the intestinal absorption of carbohydrates } \\
\text { Low glycaemic index }\end{array}$ & {$[72]$} \\
\hline \multirow[t]{2}{*}{ Diabetes } & Dietary fibre & Slow glucose release and low glycaemic load & {$[72]$} \\
\hline & $\begin{array}{l}\text { Protein concentrates rich } \\
\text { in antioxidants }\end{array}$ & $\begin{array}{l}\text { Seed coat phenolics act as inhibitors which decrease postprandial hyperglycaemia by } \\
\text { blocking the action of complex carbohydrate hydrolyzing enzymes (amylase, alpha- } \\
\text { glucosidase); increase in adinopectin concentration may improve insulin sensitivity }\end{array}$ & {$[71]$} \\
\hline \multirow[t]{3}{*}{$\begin{array}{l}\text { Cardiovascular } \\
\text { diseases }\end{array}$} & $\begin{array}{l}\text { Protein concentrate of } \\
\text { foxtail millet }\end{array}$ & $\begin{array}{l}\text { Elevated levels of adinopectin which protects cardiovascular tissues by: } \\
\text { (1) Inhibition of pro-inflammatory and hypertrophic response } \\
\text { (2) Stimulation of endothelial cell responses }\end{array}$ & {$[67]$} \\
\hline & $\begin{array}{l}\text { Administration of proso/ } \\
\text { foxtail millet }\end{array}$ & $\begin{array}{l}\text { Reducing plasma triglycerides, } L D L \text { through improved cholesterol metabolism } \\
\text { Lower C reactive protein: a marker of inflammation and a stronger predictor of cardio- } \\
\text { vascular events in clinical applications }\end{array}$ & {$[68]$} \\
\hline & $\begin{array}{l}\text { Phenolic extracts from } \\
\text { seven millet varieties } \\
\text { (kodo, finger proso, } \\
\text { foxtail, little and pearl } \\
\text { millet }\end{array}$ & $\begin{array}{l}\text { Kodo millet exhibited higher inhibition to lipid peroxidation, analogous to butylated } \\
\text { hydroxyanisole at } 200 \text { ppm }\end{array}$ & {$[63]$} \\
\hline \multirow[t]{2}{*}{ Cancer } & $\begin{array}{l}\text { Phenolic extracts from } \\
\text { seven millet varieties } \\
\text { (kodo, finger proso, } \\
\text { foxtail, little and pearl } \\
\text { millet }\end{array}$ & $\begin{array}{l}\text { Inhibition of lipid peroxidation in liposomes, singlet oxygen quenching and inhibition } \\
\text { of DNA scission } \\
\text { Millet extracts inhibited } \mathrm{H}-29 \text { cell proliferation in the range of } 28-100 \% \text { after } 4 \text { days of } \\
\text { administration }\end{array}$ & {$[63]$} \\
\hline & $\begin{array}{l}35 \text { kDa protein FMBP } \\
\text { extracted from foxtail } \\
\text { millet bran extract }\end{array}$ & $\begin{array}{l}\text { FMBP, homologous to peroxidase suppress colon cancer cell growth through: } \\
\text { (1) Induction of G1 phase arrest } \\
\text { (2) Loss of mitochondrial trans-membrane potential resulting in caspase-dependent } \\
\text { apoptosis in colon cancer cells }\end{array}$ & {$[73]$} \\
\hline \multirow[t]{2}{*}{$\begin{array}{l}\text { Inflammation and } \\
\text { wound healing }\end{array}$} & $\begin{array}{l}\text { Antioxidants: } \\
50 \mathrm{~g} \text { of finger millet per } \\
100 \mathrm{~g} \text { feed in diabetic } \\
\text { and non-diabetic rats }\end{array}$ & $\begin{array}{l}\text { Enhances dermal wound healing process in diabetes with oxidative stress-mediated } \\
\text { modulation of inflammation }\end{array}$ & {$[74]$} \\
\hline & $\begin{array}{l}\text { Administration of proso/ } \\
\text { foxtail millet }\end{array}$ & Lower $C$ reactive protein & {$[68]$} \\
\hline Ageing & $\begin{array}{l}\text { Antioxidant: } \\
\text { Methanolic extract of } \\
\quad \text { finger millet }\end{array}$ & $\begin{array}{l}\text { Inhibit glycation and cross-linking of collagen } \\
\text { Scavange free radicals in protection against ageing }\end{array}$ & {$[69]$} \\
\hline \multirow[t]{2}{*}{$\begin{array}{l}\text { Anti-microbial } \\
\text { activity }\end{array}$} & $\begin{array}{l}\text { Protein extracts, poly- } \\
\text { phenols }\end{array}$ & $\begin{array}{l}\text { Anti-fungal and antibacterial activity: } \\
\text { active against Bacillus cereus, Aspergillus niger }\end{array}$ & {$[75]$} \\
\hline & $\begin{array}{l}\text { Seed coat phenolic } \\
\text { extract }\end{array}$ & $\begin{array}{l}\text { Loss of fungal functionality by: } \\
\text { (1) Oxidation of microbial membranes and cell components by the free radicals } \\
\text { (2) Inactivation of enzymes due to irreversible complex formation with nucleophilic } \\
\text { amino acids } \\
\text { (3) Complex formation of phenolic compounds with biopolymers such as proteins, } \\
\text { polysaccharides and metal ions making them unavailable to micro-organisms }\end{array}$ & {$[76]$} \\
\hline $\begin{array}{l}\text { Ocular diseases } \\
\text { and disorders }\end{array}$ & $\begin{array}{l}\text { Polyphenols, flavanoids: } \\
\text { Wistar rats maintained on } \\
5 \% \text { finger millet seed } \\
\text { coat matter (SCM) for } \\
6 \text { weeks }\end{array}$ & $\begin{array}{l}\text { (1) Direct scavenging of reactive oxygen species (ROS), anti-apoptotic activity, and } \\
\text { phase } 2 \text { induction } \\
\text { (2) Inhibiting nitric oxide (NO) production } \\
\text { (3) Inhibiting certain enzymes responsible for the production of superoxide anions } \\
\text { (xanthine oxidase and protein kinase C) } \\
\text { (4) Prevents the accumulation of sorbitol by inhibiting aldose reductase by non-com- } \\
\text { petitive inhibition and reduce the risk of diabetes-induced cataract diseases }\end{array}$ & {$[77,78]$} \\
\hline Coeliac Disease & Protein of all millets & Absence of gluten in millet protein prevents coeliac disease and related complications & {$[79]$} \\
\hline
\end{tabular}


the protein digestibility. Irradiation has also shown inhibitory effect against anti-nutrients, and it enhances the protein digestibility [84]. Extrusion cooking or high temperature short time (HTST) processing has been reported to reduce anti-nutrients like phytates, tannins and increase bioavailability of minerals [52].

\section{Millet-based contemporary foods}

Nutritional quality and drought-resistant properties of millets have drawn attention of various research agencies all over the world and have increased focus to improve the millet varieties and to enhance their use in processed food products. A schematic diagram for the preparation of composite foods from millets is shown in Fig. 2. Some of the research work carried on the utilization of millet crops is discussed in this section.

\section{Cookies}

Shadang and Jaganathan [85] formulated the bakery products like biscuits, cakes and cookies using foxtail millet, finger millet, proso millet and pearl millet added with wheat flour. For biscuit and cake, the ratios of 10:90, 20:80 and 30:70 were selected, whereas for cookies, the flours were used in the ratios of 15:85, 20:80 and 25:75, respectively. The sensory evaluation of their products revealed that the combinations of all the three levels were well acceptable for the three products. Rai et al. [86] utilized alternate flours/meals based on rice (Oryza sativa), maize (Zea mays), sorghum (Sorghum vulgare) and pearl millet (Pennisetum glaucum) for the preparation of gluten-free cookies. Their study revealed that the combination of pearl millet and sorghum flour had the maximum sensory scores followed by the cookies prepared from rice and sorghum, maize and pearl millet, rice and pearl millet and control cookies. Best pasting properties were obtained from blends of maize and pearl millet followed by pearl millet and sorghum flour. However, maximum yield was obtained in control (wheat) cookies, i.e. 186.8\%, while cookies prepared from rice and maize had the highest spread ratio. The cookies prepared from blend of pearl millet and sorghum was nutritionally rich and had higher fat, protein, ash and calorific values.

Surekha et al. [87] prepared the barnyard millet flourbased cookies with three different variations, viz. plain, pulse and vegetable. Their research findings indicated that among the three treatments, pulse cookies $(90 \%$ barnyard millet flour $+10 \%$ soybean and green gram flour) had the highest (85\%) overall acceptability followed by vegetable cookies ( $90 \%$ barnyard millet flour $+10 \%$ dehydrated carrots) with $80 \%$ overall acceptability with the least acceptability of $73.33 \%$ plain barnyard millet varieties. These cookies had a significant increase in macronutrient and micronutrient composition as compared to simple wheat flour-based cookies.

\section{Bread}

Ballolli et al. [88] prepared bread using varying concentrations of wheat flour and foxtail millet. It was found that wheat flour can be successfully replaced with foxtail millet flour up to $50 \%$ without significant effect on flavour and overall acceptability. However, the scores for colour, texture and appearance were reduced as compared to controlled sample. Addition of foxtail millet also resulted in a slight increase in the total protein and mineral content in comparison to the control bread.

\section{Biscuits}

Anju and Sarita [89] prepared biscuits using foxtail and barnyard millet. In the recipe, refined wheat flour was replaced to $45 \%$ with millet flour and all other ingredients like hydrogenated fat, eggs, baking powder and curd were same as the standard process for the biscuit making. The sensory evaluation of millet-based biscuits revealed a good overall acceptability and had a higher content of crude fibre, total ash and total dietary fibre as compared to refined wheat flour biscuits. Biscuits from foxtail millet flour had the lowest glycaemic index (GI) of $50.8 \mathrm{com}$ pared to 68 for biscuits from barnyard millet flour and refined wheat flour.

Pearl millet flour-based sweet, salty and cheese biscuits were prepared and reported by Sehgal and Kwatra [90]. Different blends containing pearl millet flour (40-80\%), refined wheat flour (10-50\%) and green gram flour (10\%) were prepared. The sweet and salty biscuits prepared from refined wheat flour, blanched pearl millet and green gram were nutritionally sound as compared to biscuits prepared from wheat flour alone but had higher antinutrient (polyphenol and phytic acid) content.

Saha et al. [91] prepared biscuits from composite flour containing finger millet and wheat flour in the ratio of 60:40 and 70:30 $(w / w)$. The hardness of biscuit dough was more in blend of 60:40 than 70:30 levels. An increase in adhesiveness and resistance of biscuit dough was found with the increasing levels of wheat flour. But the blend of 70:30 showed more breaking strength and expansion of biscuit after baking in comparison to blend of 60:40.

\section{Snack foods}

Dhumal et al. [92] developed potato and barnyard millet-based oil free, microwave puffed ready-to-eat fasting foods. Barnyard millet flour and potato mash, i.e. 50:50, $55: 45$ and 60:40, were prepared in three proportions and was steamed for 10,15 and $20 \mathrm{~min}$. Appropriate cold extrudates were obtained from mixture of barnyard millet flour and potato mash (55:45) after steaming 


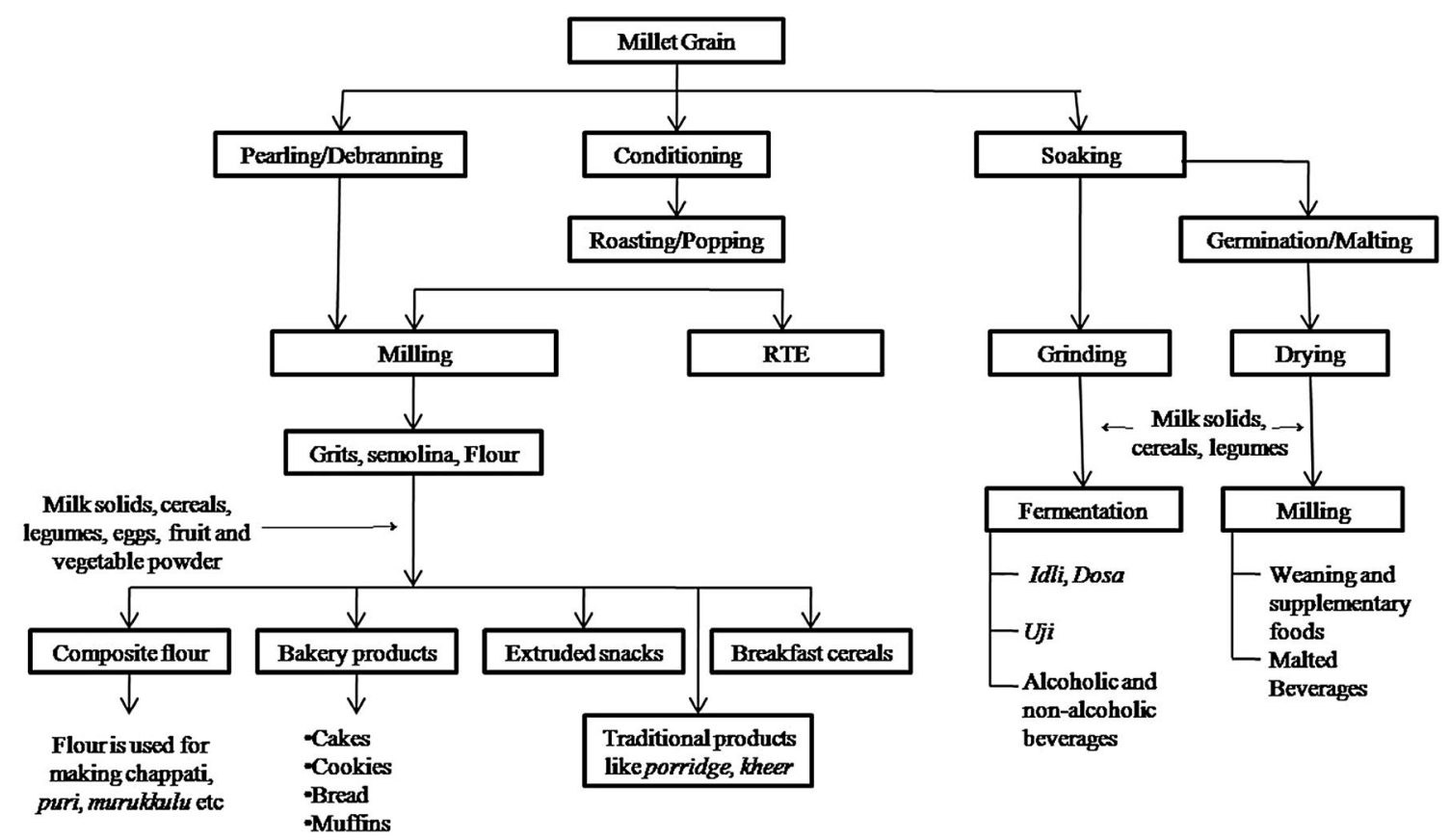

Fig. 2 Schematic diagram for developing millet-based composite foods

the dough rolled in $50 \mathrm{~mm}$ thickness in kitchen pressure cooker $\left(1 \mathrm{~kg} / \mathrm{cm}^{2}\right.$ pressure) for $15 \mathrm{~min}$. The cold extrudates prepared after steaming for 10 min were very white while that prepared after steaming for 20 min were brown in colour.

A Barnyard millet-based ready-to-eat snack food was prepared by Jaybhaye and Srivastav [80], in which barnyard millet, potato mash and tapioca powder was used in the proportion of 60:37:3. The dough was formed into thin rectangular-shaped, steam-cooked cold extrudate samples and was puffed with HTST puffing process at optimum temperature and time $\left(238{ }^{\circ} \mathrm{C} / 39.35 \mathrm{~s}\right)$. The puffed product had a moisture content of $9 \%$ and an expansion ratio of 2.05 . After puffing, the product was oven-toasted at $116.26^{\circ} \mathrm{C}$ for $20-23 \mathrm{~min}$.

\section{Multigrain flour}

Kamaraddi and Shanthakumar [93] prepared multigrain flour by incorporating various millet flours. They concluded that the substitution of wheat flour with $10-20 \%$ of millet flour was possible. They optimized $10 \%$ substitution of finger, foxtail and little millet. The proso millet can be replaced to a level of $15 \%$ and barnyard millet up to $20 \%$. The further increase in millet content resulted in a lower gluten content, sedimentation value, loaf volume of dough and decreased content of proteins in some flours as compared to wheat flour. The addition of millet also changed the colour of crumb from creamish white to dull brown. An increase in protein, ash and fat content was observed on addition of some millet flours.

\section{Traditional millet-based products}

Millets has been used for the purpose of food and feed from ancient times and has been a staple food particularly in diets of African and Asian people. These are consumed as flat bread, porridge, roasted and alcoholic and non-alcoholic beverages (Fig. 2). Millet porridge is a traditional food in Indian, Russian, German and Chinese cuisines. Millets are also used to replace commonly used cereals in local dishes like idli, puttu, adai, dosa, etc. Other traditional products like baddis, halwa, burfi, papad with added millet are also reported [68, 94, 95].

\section{Non-alcoholic products Appalu}

Appalu is made from a mixture of pearl millet flour and Bengal gram flour. Spices like sesame seeds, carom seeds, chilli powder and salt are added and kneaded into dough. Then, the dough is divided into small balls and flattened into round shape. These are then fried and served hot.

\section{Samaipayasam}

The word samai means little millet while payasam means kheer. For preparation of samaipayasam, roasted groundnuts, fennel and jaggery are ground into a fine powder separately. Little millet is added to boiling water by constantly stirring. After the flour is stirred in, jaggery 
solution is added and the mixture is cooked for a few minutes on low flame. This dish is served hot. This recipe is also made with other millets instead of little millet [96].

\section{Korramurukulu}

This crispy savoury Indian snack is prepared from a mixture of foxtail millet flour, Bengal gram flour. To this, small amount of spices like cumin seeds, chilli powder, sesame seeds and salt are added and formed into stiff dough with the help of water. The dough is placed in the hand extruder and murukus extruded are deep-fried until these turn brown [97].

\section{Alcoholic beverages}

\section{Sur}

It is a finger millet-based (Eleucine coracana) fermented beverage mostly prepared in the Lug valley of Kullu; Bhangal, Luharti of Kangra district, Balh valley, Barot valley of district Mandi and regions of Sirmour, Himachal Pradesh, India [98, 99]. A mixture (inocula) of roasted barley and local herbs known as 'dhaeli' is used to carry out fermentation. The millet flour is kneaded with water to make dough and left in a container for 7-8 days for natural fermentation. The fermented flour is half baked into rotis, cut to pieces and cooled. Then, the roti pieces and powdered dhaeli with sufficient amount of water and jaggery are put into smoke-treated earthen pots and allowed to ferment for 10 days by covering the pot. After the completion of fermentation, liquid is filtered and stored in specially designed earthen pots, sealed air tight from the top. The product has been reported to have $5-10 \%$ of alcohol [99].

\section{Madua}

Madua is among the most popular finger-millet-based beverage prepared in Arunachal Pradesh. The millet is roasted for $30 \mathrm{~min}$ followed by cooling and cooking until soft. The softened grains are mixed with starter culture and allowed to ferment in a perforated basket covered with Ekam leaves for 4-7 days. After completion of fermentation, hot water is poured from top and collected in a container. The collected liquid is known as madua. A good quality madua is golden yellow in colour, sweet in taste and has good alcoholic flavour. Themsing, rakshi, mingri and lohpani are other finger millet-based alcoholic beverages produced and consumed in Arunachal Pradesh, India [100].

\section{Oshikundu}

Oshikundu is a traditional cereal-based sour-sweet beverage of Namibia. It exits in both alcoholic and non-alcoholic form. It is brewed from pearl millet (Pennisetum glaucum) meal locally known as mahangu, malted sorghum (Sorghum bicolor), bran and water. Brewing of oshikundu is a household practice by rural women for their daily household consumption and for sale in the open markets in some towns of northern Namibia. The production process involves the addition of boiled water to mahangu meal, and the mixture is left to cool to room temperature with occasional stirring. Malted sorghum meal and bran are then added to the mixture. The step of bran addition is optional depending on the availability and preference of using bran in brewing. After the preparation of mixture, some amount of previously fermented oshikundu is added. The final mixture is then diluted with water depending on the amount of starting material used and desired volume of the final product. The mixture is then left to ferment at room temperature for an average one and half hour after which oshikundu is ready to drink. The alcohol is produced by the yeast fermentation of malt sorghum. It is a perishable beverage with a shelf life of less than 6 hours and is drunk on the same day [101].

\section{Koozh}

Koozh is another fermented beverage made with millet flour and rice and consumed mainly by ethnic communities in Tamil Nadu, India [102]. It is mainly prepared using finger millet (Eleucine corcana); however, use of pearl millet has been reported in other places. The preparatory steps of koozh involve two fermentation stages. The process starts with grinding of the millet to flour, mixing with subsequent water to make slurry and left this to ferment overnight. On the second day, broken rice (20\% by weight of millet) is cooked in excess water, into which the overnight fermented millet slurry is mixed and cooked to make a thick porridge called noyee. The fermentation of this porridge for $24 \mathrm{~h}$ results in kali, a semisolid porridge to which the required amount of potable water was added $(1: 6 \mathrm{w} / \mathrm{v})$ and hand-mixed with salt to prepare koozh.

\section{Acceptability of millet-based products}

The effect of addition of millets on the sensory acceptability of food products is scanty. Some researchers have reported the increased acceptability of the products on addition of millets, and literature on the decreased acceptability is also available. Florence et al. [103] reported high sensory acceptability in pearl millet-based cookies. Okpala et al. [104] reported a sensory acceptability of 7.1 on a scale of 9.0 points for $100 \%$ sorghumbased cookies. The acceptability was increased to 7.2 when a blend of cocoyam flour, fermented sorghum flour and germinated pigeon pea flour was used in the ratio of 66.6:16.7:16.7, respectively. In a study based on extruded products prepared from sorghum flour, corn flour, whey 
protein isolate and defatted soy flour, decreased acceptability was reported with increased content of sorghum [105]. The use of millets as a blend with other cereals, pulses or legume has been reported to have an increase in overall acceptability of the product [104-106]. In addition to sensory aspects, the presence of anti-nutritional factors like phytic acid, tannins and phenols limits the use of millets as food [105]. High content of phytic acid was reported in the biscuits prepared using pearl millet [104]. Similar results have been reported by Mbithi-Mwikya et al. [50] in composite mix developed from unprocessed finger millet, kidney beans, peanuts and mango puree. The products were reported to be unfit for the infant consumption due to the presence of phytic acid, trypsin inhibitor and tannins content. However, the processing methods like roasting, malting, germination and soaking have been reported to reduce the anti-nutritional content $[82,105]$.

\section{Conclusions}

Millets can easily thrive in extreme conditions like drought, and some wild varieties can even prevail in flooded areas and swampy grounds. These have low glycaemic index, abode gluten-free protein and are rich in minerals (calcium, iron, copper, magnesium, etc.), B-vitamins and antioxidants. These extraordinary traits make them nutritious and climate change compliant crops. These can not only serve as an income crop for farmers but also improve the health of the community as a whole. Existing limitations, i.e. the presence of anti-nutritional factors and low sensory acceptability of millet-based products, can be overcome by the scientific interventions. The anti-nutritional factors can be inactivated by processing methods like cooking, roasting, germination and fermentation. The sensory acceptability of milletbased products can be enhanced by mixing millet flours with other flours of high acceptability and preparing composite foods. The use of millets in commercial/packaged food will encourage farmers to grow millets and will open new opportunities and revitalize the farmers. The inclusion of millet-based foods in international, national and state-level feeding programs will help to overcome the existing nutrient deficiencies of protein, calcium and iron in developing countries.

\begin{abstract}
Authors' contributions
AK and VT carried out a major part of the literature review, drafted the manuscript and are equally first author. A Kaur co-authored, supervised the manuscript preparation and helped to finalize the manuscript. VK and KG carried out literature review for selected sections and helped to revise the manuscript. All authors read and approved the final manuscript.
\end{abstract}

\section{Author details}

1 Food Science and Technology, Punjab Agricultural University, Ludhiana, Punjab 141004, India. ${ }^{2}$ Food Technology and Nutrition, School of Agriculture, Lovely Professional University, Phagwara, Punjab 144411, India.

\section{Acknowledgements}

The authors are thankful to Department of Food Science and Technology, PAU, Ludhiana and Lovely Professional University for providing the necessary facilities, which were used for the preparation of manuscript.

\section{Competing interests}

The authors declare that they have no competing interests.

Availability of data and materials

Not applicable.

\section{Consent for publication}

Not applicable.

Ethics approval and consent to participate

Not applicable.

Funding

This research work has no funding.

\section{Publisher's Note}

Springer Nature remains neutral with regard to jurisdictional claims in published maps and institutional affiliations.

Received: 7 March 2018 Accepted: 12 April 2018

Published online: 27 April 2018

\section{References}

1. FAO. World food situation; 2017. http://www.fao.org/worldfoodsituation/csdb/en/. Accessed 25 Jul 2017.

2. Huang J, Haipeng YH, Xiaodan GX, Wang G, Guo R. Accelerated dryland expansion under climate change. Nat Clim Change. 2016;6:166-71.

3. ICRISAT. Small Millets. http://www.icrisat.org/homepage. Accessed 16 Apr 2017.

4. ICRISAT. ICRISAT adds finger millet as its 6th mandate crop; 2015. http:// www.icrisat.org/newsroom/news-releases/nr-2015/ICRISAT-addsfinger-millet-6th-mandate-crop.pdf. Accessed 23 May 2017.

5. World Bank. Agriculture and Food; 2017. http://www.worldbank.org/ en/topic/agriculture/overview. Accessed 22 Mar 2018.

6. Sharma D. More than make in India, Jaitley needs to focus on farm in India. The wire; 2016. https://thewire.in/22520/budgeting-for-agriculture-and-revitalising-the-economy/. Accessed 23 Jan 2018.

7. Kajuna. STAR MILLET: Post-harvest operations. Food and Agricultural Organization, United Nations; 2001. http://www.fao.org/3/a-av009e.pdf. Accessed 27 Oct 2017.

8. Saleh ASM, Zhang Q, Chen J, Shen Q. Millet grains: nutritional quality, processing, and potential health benefits. Compr Rev Food Sci Food Saf. 2013;12:281-95.

9. Awika JM. Major cereal grains production and use around the world. In: Advances in cereal science: implications to food processing and health promotion. American Chemical Society; 2011. p. 1-13.

10. Sharma CP. Overdraft in India's water banks: studying the effect of production of water intensive crops on ground water depletion. Master Thesis-Georgetown University, Washington DC; 2016.

11. National Rainfed Area Authority (NRRA); 2012. http://www.indiaenvironmentportal.org.in/category/28905/publisher/national-rainfed-areaauthority/. Accessed 4 Jan 2018.

12. Gangaiah. Agronomy-Kharif Crops Finger Millet; 2008. http://nsdl.niscair.res.in/jspui/bitstream/123456789/527/1/Millets\%20(Sorghum,\%20 Pearl\%20Millet,\%20Finger\%20Millet)\%20-\%20\%20Formatted.pdf. Accessed 23 Mar 2018.

13. International Rice Research Institute (IRRI). Steps to successful rice production. Rice production manual, Los Banos (Phillipines); 2015. wwW. knowledgebank.irri.org. Accessed 28 Jun 2017.

14. Hulse JH, Laing EM, Pearson OE. Sorghum and the millets. New York: Their composition and nutritional value. Academic Press; 1980. 
15. Food and Agricultural Organization (FAO). Crop salt tolerance data. Agricultural drainage management in arid and semi-arid crops; 1985. http://www.fao.org/docrep/005/y4263e/y4263e0e.htm. Accessed 23 May 2017.

16. Farmers portal; 2017. http://farmer.gov.in/imagedefault/pestanddiseasescrops/wheat.pdf. Accessed 15 Jun 2017.

17. Dixon GE. Sorghum. In: Doggett H, editor. London: Longmans, Green; 1970. p. 403.

18. Fageria NK, Baligar VC, Jones CA. Growth and mineral nutrition of field crops. Boca Raton: CRC Press; 2010.

19. Hannaway DB, Larson C. Forage fact sheet: pearl millet (Pennisetum americanum). Corvallis: Oregon State University; 2004.

20. Satish L, Rathinapriya P, Rency SA, Ceasar SA, Prathibha M, Pandian S, Kumar R, Ramesh M. Effect of salinity stress on finger millet (Eleusine coracana (L.) Gaertn): histochemical and morphological analysis of coleoptile and coleorhizae. FLORA. 2016;222:111-20.

21. Habiyaremye C, Matanguihan JB, D'Alpoim Guedes J, Ganjyal GM, Whiteman MR, Kidwell KK, Murphy KM. Proso millet (Panicum miliaceum L.) and its potential for cultivation in the Pacific Northwest, US: a review. Front. Plant Sci. 2017;7:1961.

22. Brink M. Setaria italica (L.) P. Beauv. Record from Protabase. In: Brink M, Belay G, editors. PROTA (Plant Resources of Tropical Africa/Ressourcesvégétales de l'Afrique tropicale), Wageningen, Netherlands; 2006.

23. Hariprassana K. Foxtail millet, Setaria italica (L.) P. Beauv. In: Jagananth PV, editor. Millets and sorghum: biology and genetic improvement. Wiley: New York; 2017. p. 112-48.

24. Krishnamurthy L, Upadhyaya HD, Gowda CLL, Kashiwagi JR, Singh Purushothaman S, Vadez V. Large variation for salinity tolerance in the core collection of foxtail millet (Setaria italica L.) germplasm. Crop Pasture Sci. 2014;65(4):353-61.

25. Farrell W. Plant guide for billion-dollar grass (Echinochloa frumentacea), USDA-Natural Resources Conservation Service; 2011.

26. Mitchell WA. Japanese millet (Echinochloa crus galli var. frumentacea) Sect. 7.1.6, US Army Corps of Engineers Wildlife Resources Management Manual. Technical Report EL-89-13. Department of Defense Natural Resources Program. US Army Engineer Waterways Exp. Stat., Vicksburg, Missisippi; 1989.

27. Kannan SM, Thooyavathy RA, Kariyapa RT, Subramanian K, Vijayalakshmi K. Seed production techniques for cereals and millets. In: Vijayalakshmi $\mathrm{K}$, editor. Seed node of the revitalizing rainfed agriculture network Centre for Indian knowledge systems (CIICS). 2013. p. 1-39. http:// www.ciks.org/downloads/seeds/5.\%20Seed\%20Production\%20Techniques\%20for\%20Cereals\%20and\%20Millets.pdf. Accessed 29 Dec 2017.

28. Dayakar RB, Bhaskarachary K, Arlene Christina GD, Sudha Devi G, Tonapi A. Nutritional and health benefits of millets. ICAR. Indian Institute of Millets Research (IIMR) Rajendranagar, Hyderabad, 2017; p. 112.

29. Joel A, Kumaravadivel N, Nirmalakumari A, Senthil N, Mohanasundaram K, Raveendran T, Mallikavangamudi V. A high yielding Finger millet variety CO (Ra) 14. Madras Agric J. 2005;92:375-80.

30. ICAR- Indian Institute of Millets Research. Millets annual report 2016-17; 2017. http://millets.res.in/annual_report/ar16-17.pdf. Accessed 27 Mar 2018.

31. Recommended package of practices: pearl millet. http://millets.res.in/ technologies/Recommended_package_of_practices-Pearl_millet.pdf. Accessed 26 Mar 2018.

32. State of diversity of major and minor crops (Appendix 4) http://www. fao.org/docrep/013/i1500e/i1500e14.pdf. Accessed 27 Mar 2018.

33. Balasubramanian S, Vishwanathan R, Sharma R. Post-harvest processing of millets: an appraisal. Agric Eng Today. 2007;31(2):18-23.

34. United Nations Children Fund. From promise to impact: ending malnutrition by 2030; 2016 https://data.unicef.org/wp-content/ uploads/2016/06/130565-1.pdf. Accessed 24 Mar 2018.

35. IFPRI. Global Nutrition Report: Malnutrition Becoming the "New Normal" Across the Globe; 2016. https://www.ifpri.org/news-release/ global-nutrition-report-malnutrition-becoming-\%E2\%80\%9Cnewnormal\%E2\%80\%9D-across-globe. Accessed 24 Mar 2018.

36. FAO. The State of Food Insecurity in the World 2015. Food and Agricultural Organization of the United Nations; 2015. http://www.fao.org/ worldfoodsituation/csdb/en/. Accessed 15 Mar 2017.
37. WHO. Obesity and overweight Fact sheet $\mathrm{N}^{\circ} 311^{\prime \prime} ; 2015$. http://www. who.int/mediacentre/factsheets/fs311/en/. Accessed 23 Jan 2018.

38. WHO. Overweight and obesity. Global Health Observatory (GHO) data; 2016. http://www.who.int/gho/ncd/risk_factors/obesity_text/en/. Accessed 23 Jan 2018.

39. Von Grebmer K, Bernstein J, Hossain N, Brown T, Prasai N, Yohannes Y. 2017 global hunger index: The inequalities of hunger. International Food Policy Research Institute. 2017. http://www.globalhungerindex. org/pdf/en/2017.pdf. Accessed 21 Jan 2018.

40. Lozano R, Naghavi M, Foreman K. Global and regional mortality from 235 causes of death for 20 age groups in 1990 and 2010: a systematic analysis for the Global Burden of Disease Study 2010. Lancet. 2012;380:2095-128.

41. Gragnolatia M, Shekarb M, Gupta MC, Bredenkampd C, Lee Y. India's undernourished children: A call for reform and action, health, nutrition and population (HNP) discussion paper. Washington DC: World Bank; 2005.

42. National Family Health Survey. National Family Health Survey 2015-16: India. Mumbai, India: International Institute for Population Sciences; 2017. http://rchiips.org/NFHS/factsheet_NFHS-4.shtml. Accessed 28 Mar 2018.

43. Gol. Ministry of Women and Child Development Government of India Rapid Survey on Children 2013-2014 India Factsheet; 2015.

44. Kaveeshvar SA, Cornwall J. The current state of diabetes mellitus in India. Australas Med J. 2014;7(1):45-8.

45. Misra A, Shah P, Goel K, Hazra DK, Gupta R, Seth P, Tallikoti P, Mohan I, Bhargava R, Bajaj S, Madan J, Gulati S, Bhardwaj S, Sharma R, Gupta $\mathrm{N}$, Pandey RM. The high burden of obesity and abdominal obesity in urban Indian schoolchildren: a multicentric study of 38,296 children. Annal Nutrit Metab. 2011;58(3):203-11.

46. Leder I. Sorghum and Millets. Cultivated plants, primarily as food sources. In: Gyargy F, editor. Encyclopedia of life support systems, UNESCO, Eolss Publishers, Oxford; 2004.

47. Baebeau WE, Hilu KW. Plant foods. Human Nutrition. 1993;43(2):97-104.

48. Panghal A, Khatkar BS, Singh U. Cereal proteins and their role in food industry. Indian Food Indus. 2006;25(5):58-62.

49. Singh $P$, Raghuvanshi SR. Finger millet for food and nutritional security. Afr J Food Sci. 2012;6:77-84

50. Mbithi-Mwikya S, Ooghe W, Van Camp J, Nagundi D, Huyghebaert A. Amino acid profile after sprouting, Autoclaving and lactic acid fermentation of finger millet (Elusine coracana) and kidney beans (Phaseolus vulgaris L.). J Agric Food Chem. 2000;48:3081-5.

51. FAO. Amino Acid Scoring Pattern. In Protein quality evaluation, FAO/ WHO Food and Nutrition Paper, Italy. 1991;12-24.

52. Nirmala M. Subbarao MVSST, Muralikrishna G. Carbohydrates and their degrading enzymes from native and malted finger millet (Ragi, Eleusine corcana, Indaf-15). Food Chem. 2000;69:175-80.

53. Manisseri C, Gudipati M. Prebiotic Activity of Purified Xylobiose obtained from Ragi (Eleusine coracana, Indaf-15) bran. Indian J Med Microbiol. 2012;52(2):251-7.

54. Mathanghi SK, Sudha K. Functional and phytochemical properties of finger millet (Eleusine coracana L.) for health. Int J Pharm Chem Biol Sci. 2012:2(4):431-8.

55. Shobana S, Malleshi NG. Preparation and functional properties of decorticated finger millet (Eleusine coracana). J Food Engg. 2007;79:529-38

56. Englyst HN, Kingman SM, Cummings JH. Classification and measurement of nutritionally important starch fractions. Eur J Clin Nutr. 1992;46(2):33-50.

57. Chandel G, Kumar M, Dubey M, Kumar M. Nutritional properties of minor millets: neglected cereals with potentials to combat malnutrition. Curr Sci. 2014;107(7):1109-11.

58. Millet Network of India. Millets: future of food and farming; 2016. http:// www.swaraj.org/shikshantar/millets.pdf2016. Accessed 3 March 2017.

59. Pontieri P, Troisi J, Fiore RD, Bean SR, Roemer E, Boffa A, Giudice AD, Pizzolante G, Alifano P, Giudice LD. Mineral contents in grains of seven food grade sorghum hybrids grown in mediterranean environment. J Crop Sci. 2014;8(11):1550-9.

60. Soetan KO, Olaiya CO, Oyewole OE. The importance of mineral elements for humans, domestic animals and plants - a review. Afr J Food Sci. 2010;4(5):200-22. 
61. Aggarwal V, Seth A, Aneja S, Sharma B, Sonkar P, Singh S, Marwaha RK. Role of calcium deficiency in development of nutritional rickets in Indian children: a case control study. J Clin Endocrinol Metab. 2012;97(10):3461-6.

62. Platel K. Millet flours as a vehicle for fortification with iron and zinc. In: Preedy VR, Srirajaskanthan R, Patel VB, editors. Handbook of food fortification and health, eds. New York: Springer; 2013. p. 115-23.

63. Chandrasekara A, Shahidi F. Determination of antioxidant activity in free and hydrolyzed fractions of millet grains and characterization of their phenolic profiles by HPLC-DAD-ESI-MSn. J Funct Foods. 2011;3:144-58.

64. Devi PB, Vijayabharathi R, Sathyabama S, Malleshi NG, Priyadarisini VB. Health benefits of finger millet (Eleusine coracana L.) polyphenols and dietary fiber: a review. J Food Sci Technol. 2014;51(6):1021-40.

65. Dykes L, Rooney LW. Review sorghum and millet phenols and antioxidants. J Cereal Sci. 2006:44:236-51.

66. Sireesha Y, Kasetti RB, Nabi SA, Swapna S, Apparao C. Antihyperglycemic and hypolipidemic activities of Setaria italica seeds in STZ diabetic rats. Pathophysiology. 2011;18:159-64.

67. Choi YY, Osada Y. Ito, Nagasawa T, Choi MR, Nishizawa N. Effects of dietary protein of Korean foxtail millet on plasma adiponectin, HDLcholesterol, and insulin levels in genetically type 2 diabetic mice. Biosci Biotechnol Biochem. 2005:69(1):31-7.

68. Lee SH, Chung IM, Cha YS, Park Y. Millet consumption decreased serum concentration of triglyceride and C-reactive protein but not oxidative status in hyperlipidemic rats. Nutri Res. 2010;30(4):290-6.

69. Hegde PS, Chandrakasan G, Chandra TS. Inhibition of collagen glycation and crosslinking in vitro by methanolic extracts of finger millet (Eleusine coracana) and kodo millet (Paspalum scrobiculatum). J Nutr Biochem. 2002;13:517-21.

70. Shashi BK, Sharan S, Hittalamani S, Shankar AG, Nagarathna TK. Micronutrient composition, antinutritional factors and bioaccessibility of iron in different finger millet (Eleusine coracana) genotypes. Karnataka J Agric Sci. 2007;20(3):583-5.

71. Shobana S, Sreerama YN, Malleshi NG. Composition and enzyme inhibitory properties of finger millet (Eleusine coracana L.) seed coat phenolics: mode of inhibition of a-glucosidase and a-amylase. Food Chem. 2009;115:1268-73.

72. Jenkins DJA, Jenkins MA, Wolever TMS, Taylor RH, Ghafari H. Slow release carbohydrate: mechanism of action of viscous fibers. J Clin Gastroenterol. 1986;1:237-41.

73. Shan S, Li Z, Newton IP, Zhao C, Li Z, Guo M. A novel protein extracted from foxtail millet bran displays anticarcinogenic effects in human colon cancer cells. Toxicol Lett. 2014;227(2):129-38.

74. Rajasekaran NS, Nithya M, Rose C, Chandra TS. The effect of finger millet feeding on the early responses during the process of wound healing in diabetic rats. Biochem Biophys Acta. 2004;1689:90-201.

75. Viswanath V, Urooj A, Malleshi NG. Evaluation of antioxidant and antimicrobial properties of finger millet polyphenols (Eleusine coracana). Food Chem. 2009;11:340-6.

76. Siwela M, Taylor JR, de Milliano WA, Dudu KG. Influence of phenolics in finger millet on grain and malt fungal load, and malt quality. Food Chem. 2010;121:443-9.

77. Chethan S. Finger millet (Eleusine coracana) seed polyphenols and their nutraceutical potential. Mysore: Thesis-Doctorate of Philosophy. University of Mysore; 2008.

78. Harsha MR, Platel K, Srinivasan K, Malleshi NG. Amelioration of hyperglycemia and its associated complications by finger millet (Eleusine coracana) seed coat matter in streptozotocin induced diabetic rats. $\mathrm{Br}$ J Nutr. 2010;104:1787-95.

79. Jnawali P, Kumar V, Tanwar B. Celiac disease: overview and considerations for development of gluten-free foods. Food Sci and Hum Wellness. 2016;5(4):169-76.

80. Jaybhaye RV, Srivastav PP. Development of barnyard millet ready-to-eat snack food: part II. Food Sci. 2015;6(2):285-91.

81. Platel K, Eipeson SW, Srinivasan K. Bioaccessible mineral content of malted finger millet (Eleusine coracana), Wheat (Triticum aestivum), and Barley (Hordeum vulgare). J Agric Food Chem. 2010;58:8100-3.

82. Handa V, Kumar V, Panghal A, Suri S, Kaur J. Effect of soaking and germination on physicochemical and functional attributes of horsegram flour. J Food Sci Technol. 2017;54(13):4229-39.
83. Hussain I, Uddin MB, Aziz MG. Optimization of anti-nutritional factors from germinated wheat and mung bean by response surface methodology. Food Res Int J. 2011;18:957-63.

84. Pushparaj FS, Urooj A. Influence of processing on dietary fiber, tannin and in vitro protein digestibility of pearl millet. Food Nutri Sci. 2011;2:895-900.

85. Shadang C, Jaganathan D. Development and standardisation of formulated baked products using millets. Int J Res Appl Nat Soc Sci. 2014;2:75-8.

86. Rai S, Kaur A, Singh B. Quality characteristics of gluten free cookies prepared from different flour combinations. J Food Sci Technol. 2014;51:785-9.

87. Surekha N, Ravikumar SN, Mythri S, Devi R. Barnyard Millet (Echinochloa Frumentacea Link) cookies: development, value addition, consumer acceptability, nutritional and shelf life evaluation. IOSR J Environ Sci Toxicol Food Technol. 2013:7:1-10.

88. Ballolli U, Malagi U, Yenagi N, Orsat V, Garipey Y. Development and quality evaluation of foxtail millet [Setaria italica (L.)] incorporated breads. Karnataka J Agric Sci. 2014;27(1):52-5.

89. Anju T, Sarita S. Suitability of foxtail millet (Setaria italica) and barnyard millet (Echinochloa frumentacea) for development of low glycemic index biscuits. Malays J Nutr. 2010;16(3):361-8.

90. Sehgal A, Kwatra A. Use of pearl millet and green gram flours in biscuits and their sensory and nutritional quality. J Food Sci Technol. 2007:44(5):536-8.

91. Saha S, Gupta A, Singh SRK, Bharti N, Singh KP, Mahajan V, Gupta HS Compositional and varietal influence of finger millet flour on rheological properties of dough and quality of biscuit. LWT_J Food Sci Technol. 2010:44:616-21.

92. Dhumal CV, Pardeshi IL, Sutar PP, Jayabhaye RV. Development of potato and barnyard millet based ready to eat (RTE) fasting food. J Ready Eat Food. 2014;1(1):11-7.

93. Kamaraddi V, Shanthakumar G. Effect of incorporation of small millet flour to wheat flour on chemical, rheological and bread characteristics. In: Recent trends in millet processing and utilization. CCS Hisar Agricultural University. 2003. p. 74-81.

94. Malathi D, Thilagavathi T, Sindhumathi G. Traditional recipes from Banyard millet. Coimbtore: Postharvest Technology Centre, Agricultural Engineering College and Research Institute, Tamil Nadu Agricultural University; 2012.

95. Malathi D, Thilagavathi T, Sindhumathi G. Traditional recipes from kodo millet. Coimbtore: Postharvest Technology Centre, Agricultural Engineering College and Research Institute, Tamil Nadu Agricultural University; 2012.

96. Hema P. Samaipayasam/sama kheer/little millet porridge; 2017. https:// www.mylittlemoppet.com/samai-payasam-sama-kheer-little-milletporridge/. Accessed 20 Jan 2018.

97. Deccan Development Society. http://ddsindia.com/www/pdf/Millet\%20Cook\%20Book.pdf. Accessed 20 Jan 2018.

98. Joshi VK, Kumar A, Thakur NS. Technology of preparation and consumption pattern of traditional alcoholic beverage 'Sur' of Himachal Pradesh. Int J Food and Ferment Technol. 2015;5(1):75-82.

99. Kumar A. Refinement of the traditional sur production in Himachal Pradesh, Thesis-Master in Food Technology. Dr. YS Parmar University of Horticulture and Forestry, Nauni, Solan; 2013

100. Shrivastava K, Greeshma AG, Shrivastava B. Biotechnology in action-a process technology of alcoholic beverages is practices by different tribes of Arunachal Pradesh, North East India. Indian J Trad Knowl. 2012;11:81-9.

101. Werner E, Youssef A, Kahaka G. Survey on indigenous knowledge and household processing methods of oshikundu; a cereal-based fermented beverage from Oshana, Oshikoto. Ohangwena and Omusati Regions in Namibia. MRC: University of Namibia, Windhoek, Namibia; 2012.

102. Ilango S, Antony U. Assessment of the microbiological quality of koozh, a fermented millet beverage. African J Microbiol Res. 2014;8(3):308-12.

103. Florence SP, Urooj A, Asha MR, Rajiv J. Sensory, physical and nutritional qualities of cookies prepared from pearl millet (Pennisetum typhoideum). J Food Process Tech. 2014:5(10):1.

104. Okpala L, Okoli E, Udensi E. Physico-chemical and sensory properties of cookies made from blends of germinated pigeon pea, fermented sorghum, and cocoyam flours. Food Sci Nutri. 2013;1(1):8-14. 
105. Devi NL, Shobha S, Tang X, Shaur SA, Dogan H, Alavi S. Development of protein-rich sorghum-based expanded snacks using extrusion technology. Int J Food Prop. 2013;16(2):263-76.
106. Deshpande HW, Poshadri A. Physical and sensory characteristics of extruded snacks prepared from Foxtail millet based composite flours. Int Food Res J. 2011;18(2):751-6.
Ready to submit your research? Choose BMC and benefit from:

- fast, convenient online submission

- thorough peer review by experienced researchers in your field

- rapid publication on acceptance

- support for research data, including large and complex data types

- gold Open Access which fosters wider collaboration and increased citations

- maximum visibility for your research: over 100M website views per year

At BMC, research is always in progress.

Learn more biomedcentral.com/submissions 